The Canadian Journal of Higher Education La revue canadienne d'enseignement supérieur Volume XXXII, No. 3, 2002 pages 1-28

\title{
Strategies for Facilitating Success of First Nations Students ${ }^{*}$
}

\section{MARY HAMPTON \& JOAN ROY}

University of Regina

\begin{abstract}
This research suggests guidelines for college instructors which could help them facilitate success of First Nations students based on written narratives and data from four focus groups: (1) two groups of First Nations students; (2) two Faculty of Arts focus groups consisting of professors from the Saskatchewan Indian Federated College and the University of Regina who were identified as effective teachers of First Nations students. Data analysis revealed five themes that identify strategies that individual faculty members, as well as university program groups can use to create more positive learning environments for First Nations students: (1) enhancing the professor-student relationship; (2) including relevant First Nations content in curriculum; (3) using flexible teaching methods; (4) adopting a more culturally-appropriate teaching style; and (5) gaining an understanding of the unique life of a postsecondary First Nations student.

\section{RÉSUMÉ}

Cette recherche propose aux enseignants du niveau collégial des directives propres à faciliter le succès d'étudiants des Premières Nations,

* This research was funded by an institutional SSHRC grant. The authors thank Kim Jonathon, Heather Hodgson, lames McNinch, Kim McKay, and Leanne Delorme for collaborating in data collection, data analysis, and manuscript preparation; as well as Robert Roy for translating the abstract into French.
\end{abstract}


recherche basée sur des récits écrits et des renseignements recueillis de quatre groupes de discussion: (1) deux groupes d'étudiants des Premières Nations; (2) deux groupes de la Faculté des Arts composés de professeurs au Collège Indien Fédéré de la Saskatchewan et à l'Université de Régina, qui ont été identifiés comme enseignants efficaces auprès d'étudiants des Premières Nations. L'analyse des données révèle cinq thèmes qui font ressortir des stratégies que les membres du corps enseignant ainsi que les programmes universitaires peuvent utiliser pour créer des milieux d'apprentissage plus positifs pour les étudiants des Premières Nations: (1) le rehaussement de la relation professeur-étudiant; (2) l'inclusion dans le curriculum de contenus pertinents aux Premières Nations; (3) l'utilisation de méthodes d'enseignement plus flexibles; (4) l'adoption d'un style d'enseignement plus approprié à cette culture; et (5) l'atteinte d'une compréhension du vecu unique d'un étudiant des Premières Nations au niveau postsecondaire.

Multicultural education is an espoused value that has influenced goals of such professions as education and psychology (Brislin \& Horvath, 1997; Hall, Kulig, Thorpe, \& Pfeuti, 1998; Pederson, 1999). However, research evidence indicates that practice of multicultural values is only slowly impacting training in university settings (Hall et al., 1998; Simoni, Sexton-Radek, Yescavage, Richard, \& Lundquist, 1999; Sue, Bingham, Porche-Burke, \& Vasquez, 1999). Faculty members who wish to bring multiculturalism into the classroom often encounter institutional resistance or are unprepared to meet the learning needs of ethnically diverse students (Simoni et al., 1999). We are two of these faculty members who, as Caucasian women, hold multicultural values, yet struggle to fully understand issues of diversity. Our interest in this topic also came from observations that one ethnically and culturally distinct group of students, First Nations students, are present in only small numbers in our Faculty despite the fact that our university shares a student body with a First Nations controlled partner institution. The goal of this study was to understand what we, as non-native professors, could do to create more positive learning environments for First Nations students in our classrooms. 
Attention to the educational experience of First Nations students in Canada as a distinct group is warranted for several reasons: (1) rapidlychanging demographics; (2) historical relationship between First Nations peoples and formal education; and (3) the hope of good teachers to effectively meet the needs of all students. Demographic profiles of Canadian population growth indicate that First Nations populations have been increasing at about twice the rate of that of the general Canadian population (Indian and Northern Affairs Canada [INAC], 1989). Demographic projections forecast continued higher growth rates for First Nations than for the general population over the next forty years (Frideres, 1998; INAC, 1989). First Nations also comprise a young population, with one-third younger than 15 years of age and over half younger than 25 (Statistics Canada, 1995). This population trend is the reverse of other sectors in Canada. This shift means that educators will see more First Nations students in their classrooms in the coming years.

A second reason for considering First Nations as a distinct group warranting particular attention is the historical relationship between First Nations peoples and formal education. Education for assimilation has been the dominant model of education used with First Nations (Hampton, 1993). For example, under residential school policies the government removed children from parents and communities where they received a traditional Indian education with the goal of replacing the language, culture, values, worldview, institutions, and economics of First Nations with those of the dominant culture (Chrisjohn \& Young, 1997; Haig-Brown, 1988). These assimilationist methods have not only been failures, but have resulted in low educational attainment and resulting poverty. First Nations' participation rates in postsecondary education is less than one-half the national levels (INAC, 1990; Statistics Canada, 1995). Although percentages of First Nations students who attend university have steadily increased, these percentages are significantly lower than the increased percentages of the general Canadian university population (Statistics Canada, 1995). In addition, only $9 \%$ of those who start university graduate from Canadian universities, compared to $18 \%$ of non-First Nations students (Frideres, 1998). Reasons for low participation and completion rates of First Nations students in universities are 
primarily structural. Language and cultural differences, as well as effects of discrimination continue to disadvantage First Nations students in Canadian universities (Frideres, 1998). Since economic prosperity increases with higher levels of schooling, First Nations today see education as the key to a better future (Battiste \& Barman, 1995; Castellano, Davis \& Lahache, 2000).

Another compelling reason for considering the distinct needs of First Nations students is the desire of many faculty members to facilitate success of all groups of students, particularly those who have been historically disadvantaged in the formal educational system (Rhodes, 1994). Simoni et al. (1999) state that evidence from their research suggests that we have moved beyond discussing whether multiculturalism or diversity issues should be included in university settings, to asking how we can do this. Recent scholarship has challenged monocultural models of higher education which dominate university education (Fine, Weiss, Powell \& Wong, 1997; Jackson \& Solis, 1995). Some faculty members have also expressed a social justice agenda and have attempted to contribute to the global, decolonizing effort to respect the valuable contribution that indigenous knowledge offers the academy (Dei, Hall \& Rosenberg, 2000; Smith, 1999).

\section{The Setting}

The setting for our research is a mid-sized Canadian prairie university, University of Regina ( $U$ of $R$ ), with a student body of 11,700 students. One of the university's federated colleges is the Saskatchewan Indian Federated College (SIFC), a First Nations controlled universitycollege with an enrollment of 1,300 students. The relationship between these two institutions is a partnership, which allows students to access resources and take courses from both institutions. On average, the majority of students in $U$ of $R$ classes are non-First Nations and the majority of students in SIFC classes are First Nations. On an annual basis, SIFC has approximately $1,000 \mathrm{U}$ of $\mathrm{R}$ enrollments and SIFC students are enrolled in almost as many $U$ of $R$ classes. Academic programs at SIFC are meant to complement $U$ of $R$ programs, not duplicate them (Hampton \& Wolfson, 1994). 


\section{Definition of Terms}

We will use the term "First Nations" to describe the students of SIFC in order to be consistent with the Mission Statement of the College rather than as an exclusion of a greater cultural membership. The Logo of the College represents the five First Nations' tribal groups of Saskatchewan: the Cree, Saulteaux, Dene, Dakota, and Assiniboine. First Nations refers to a status/treaty Indian and is usually used to refer to a politically autonomous band under the Indian Act or a nation of First Peoples (McNinch, 2001). Because of the unique partnership of SIFC with the University of Regina, the treaty rights to education, the unique socio-historical and political structure of First Nations, we focus our research on First Nations students. We will also alternate the term First Nations with the term "Native" and refer to other ethnic groups as non-Native or non-First Nations.

\section{Research Question}

The objective of this study was to identify ways in which university professors can encourage success of First Nations students. We limit our study to one Faculty - the Faculty of Arts. Specific research objectives were: (1) to investigate, with First Nations students, areas where the University of Regina has facilitated their academic success; (2) to learn from $U$ of $R$ and SIFC faculty who have facilitated student success, ways they have achieved this goal; and (3) to use material from the above investigation to find specific strategies for non-native faculty and universities to promote more positive learning experiences for First Nations students.

\section{METHOD}

Qualitative methods were chosen as most appropriate for answering our research questions. We wanted to hear from those most knowledgeable about facilitating First Nations student success. This objective meant asking students and asking effective teachers about what works. Triangulation of data collection methods, including focus group and narrative inquiry, allowed us to combine the group-constructed experiential data with personal experience stories describing successful 
cross-cultural teaching and learning encounters (Connelly \& Clandinin, 1990; Janesick, 1998).

\section{Data Collection}

Faculty Participants. Participants were recruited for two faculty groups: one from SIFC and one from the $U$ of R. Requirements for participating were that faculty members teach in the Faculty of Arts and preferably hold permanent appointments. Since the research focus was on facilitating success, we consulted with Registration Counselors at SIFC as well as the Director of the Teaching Development Centre (TDC) at the $U$ of $R$ and asked for names of faculty who they have identified as working successfully with First Nations students. The criteria we used for measuring teacher success were adapted from the two-factor informal indicator of effectiveness advocated by Kleinfeld (1975): (1) students consistently reported significant learning as a result of contact with a professor; and (2) students combined this learning with passing grades. Invitations to participate were sent to these faculty members, all of whom agreed to participate if their schedule allowed.

Seven $U$ of $R$ faculty participated in one focus group; two others who were unable to attend due to teaching conflicts sent in narratives and written responses to the focus group questions. Six male and one female $U$ of $R$ faculty members participated; all self-reported as Caucasian on the Background Information Form. Six disciplines were represented from the Social Sciences and Humanities. Five participants stated that they attend First Nations cultural events. They reported an average of $15 \%$ First Nations students in their classes. Nine SIFC faculty members agreed to participate in the second focus group: five males and four females. Three of the SIFC faculty reported themselves as Cree and six as Caucasian. Disciplines represented in this group were English, Indian Studies, and Linguistics. All of these faculty members attend First Nations cultural events. The average number of First Nations students in their classes is $75 \%$.

Student Participants. Two First Nations psychology majors were hired as research assistants and assisted with student recruitment. Criterion for participation was that volunteers be students who have 
taken classes in the Faculty of Arts. Recruitment for two focus groups included one "younger" group (ages 29 and younger) and one "mature" group ( 30 and older). The average age of SIFC students is significantly older than $\mathrm{U}$ of $\mathrm{R}$ students, so this age breakdown seemed appropriate (Frideres, 1998). Greenbaum (1998) suggests that "age homogenous" participants in a focus group relate more easily with each other and yield better results. A sign describing the study and asking for volunteers was posted in the SIFC student lounge for four weeks. One of the research assistants was present at all times to answer questions and to sign up students for the study. Eleven students signed up for each focus group; however, all could not attend on the scheduled evenings due to class and family conflicts. Seven students participated in the younger focus group: five women and two males. Their ages ranged from 23-29 with an average age of 26. Four students participated in the older focus group: one woman and three men. Their ages ranged from 32-50, with an average age of 39. All participants in both groups were members of First Nations: nine from Saskatchewan, one from Alberta, and one from Ontario. They had completed an average of six semesters.

Instruments and Focus Groups. All participants were given a research package consisting of a cover letter, two consent forms, a background information form, and narrative guidelines. Narrative inquiry has been described as useful in educational research, since "education is the construction and reconstruction of personal and social stories; teachers and learners are storytellers and characters in their own and other's stories" (Connelly \& Clandinin, 1990, p. 2). The narrative guidelines asked participants to write a 250 word description of a successful teaching or learning encounter. Faculty members were asked to describe an experience when they had facilitated success of a First Nations student and students were asked to describe a "success" incident they had had in the Faculty of Arts. Participants returned these instruments to the researchers at the time of the focus group. These focused, personal experience stories provided vignettes of moments of success as defined by individual participants (Denzin, 1989).

Focus group outlines for faculty and student groups were developed collaboratively by researchers, student research assistants, an 
SIFC First Nations faculty member, and the Director of the Teaching Development Centre. Questions were designed to elicit descriptions of successful strategies as well as identify barriers to success. Guidelines outlined by Greenbaum (1998) for moderating and conducting focus groups were followed. Each focus group lasted approximately ninety minutes and was held on the $U$ of $R$ campus. All sessions were taperecorded for transcription.

\section{Data Analysis}

Our purposive sampling procedure was theory-driven rather than concerned with representativeness (Strauss \& Corbin, 1998). Analysis of transcripts revealed that selection of participants for the four groups offered us adequate depth for understanding our research objectives as well as opportunity for comparisons across multiple cases (Huberman \& Miles, 1998). Focus group transcripts were analyzed using the grounded theory constant comparative method (Strauss \& Corbin, 1998). We collaborated in generating 25 coding categories. Open coding of faculty transcripts was done individually; a reliability check of our coding was then conducted (Miles \& Huberman, 1994). Reliability between the researchers was acceptable ( $U$ of $R$ faculty transcripts $r=.66$; SIFC faculty transcripts $r=.68$ ). Open coding of student focus groups was done jointly. Axial and selecting coding on all transcripts was done collaboratively. Written narratives were analyzed using the holistic-content method described by Lieblich, Tuval-Mashiach, \& Zilber (1998). Several participants wrote narratives similar to Denzin's description of "turning-point" or "epiphany' moments when the personal path to successful teaching with First Nations students was illuminated (Denzin, 1989). These narratives were particularly useful and were more common among the non-Native instructors. The multiple perspectives generated individually in written format and collectively in focus groups were combined to generate strategic themes (Manning \& Cullum-Swan, 1998). Five themes which describe ways to facilitate success of First Nations students were identified. A validity check was conducted by asking two SIFC students (one of our research assistant collaborators and one of the focus group participants) to read the results and give 
detailed feedback on accuracy of the interpretation. A First Nations postsecondary educator was also consulted regarding validity of analysis. Both faculty focus group facilitators and all participants were sent copies of the summary results tables and were asked for comments and feedback, which were integrated into the analysis.

\section{WHAT DO EFFECTIVE TEACHERS AND FIRST NATIONS STUDENTS SAY?}

The results of this qualitative study are organized by the five themes that emerged from analysis of the narratives and focus group transcripts. All speakers remain anonymous, but are identified by focus group

Theme One: The professor/student relationship is the foundation for facilitating success of First Nations students.

Facilitating success of First Nations students is founded on a positive professor/student relationship. Analysis of data revealed that SIFC instructors and First Nations students consistently emphasized the primacy of relationship in their written narratives and focus group discourse. In comparison, $\mathrm{U}$ of $\mathrm{R}$ faculty indirectly alluded to positive learning relationships in successful teaching encounters. These results led us to conclude that relational factors are important for facilitating success and may be more salient for First Nation peoples. This finding is consistent with previous empirical and theoretical research (Hampton, 1993). Mitchell (2000) has described relationship-based teaching as congruent with fundamental values of many First Nation peoples. Wilson (1994) found that Native students at the University of Alaska identified the professor-student relationship as a key factor in their success or failure in university. Kleinfeld (1975) describes personal warmth as the most important quality for effective teachers of First Nations students.

This broad theme consists of several strategies that emerged from analysis of the data. The first step in establishing a positive professor/ student relationship is for professors to show First Nations students that they can be trusted. An SIFC faculty member recommends: "The other thing that $I$ can think for sure is that if you can give them the feeling that you're trustworthy and that you're on their side, then maybe that's kind 
Table 1

\section{Theme One: The Professor/Student Relationship is the Foundation for Facilitating Success of First Nations Students}

Strategy

1. Build trust

2. Get to know students

3. Gain experience in the culture

4. Be accessible

5. Engage in respectful partnership relations

\begin{abstract}
Example
"Another very important thing is that Native people we've all been abused in one form or another: mentally, emotionally, physically, and spiritually. So, when it comes down to nonnative people, we tend to put up some kind of defenses." - First Nations student
\end{abstract}

"You have to be yourself; you have to get to know your students. You have to be willing to give up some of your teaching time to talk to them about themselves." - SIFC faculty

"If you've had a lot of experience with First Nations students, First Nations people, you know the experiential difference in their background. And I guess you unconsciously adjust what you're doing with that knowledge." $-U$ of $R$ faculty

"They (non-native faculty) don't want to be stopped after class. They say, make an appointment, make an appointment."

- First Nations student

"It seems to me that SIFC students seem to see our relationship as instructor/student as more of a partnership, whereas at the $U$ of $R, I$ feel more like I'm an authority figure in a more judgmental role. So I can build on that partnership." - SIFC faculty 
of all you need." Student participants explained that trust in their professors is important because most come into postsecondary institutions with some degree of fear based on past experience:

It's so different because when I came here, you know, I was scared. Everybody who does come here is scared. Education goes back a long way with us and it's something that's been passed on to us and we have got to deal with it. Once you pass that, you're a little bit more open than you were in the beginning. (First Nations student)

The mistrust of First Nations students in higher education is a result of assimilationist policies that used educational institutions for cultural genocide (Chrisjohn \& Young, 1997). For example, long-term negative impacts of the residential school movement affect not only survivors, but their descendants as well (Haig-Brown, 1988; Hanson \& Hampton, 2000).

The next two strategies require non-native faculty to actively reach out to individual students as well as expand their knowledge of First Nations culture. Getting to know students, showing interest in their ideas and perhaps their personal lives can help faculty members perceive individuals rather than stereotypes (Hall et al., 1998). Faculty members could also seek out or take advantage of opportunities to participate in First Nations culture:

I think the non-aboriginal people don't understand our culture. They don't understand our involvement cause everybody plays different roles in different aboriginal societies. They probably don't have the time at the university, because of their studies, to get right into understanding. That's one of the big problems I think. (First Nations student)

The $\mathrm{U}$ of $\mathrm{R}$ faculty members in our focus groups who have had direct experience in cultural or traditional events found that this experience helped them get to know students and establish more positive relationships.

Finally, being accessible to students in informal ways and engaging in respectful learning partnerships are strategies which were suggested. SIFC faculty stated that it is helpful when professors are accessible through an "open-door policy," welcoming students to talk about things that may not be class-related. Students feel that non-native faculty in general tend to be less accessible, which they equate with lack of compassion: 
Compassion. Sometimes you go for help and they just kind of show you the answer and they just want to flush you out right away: "Go on, get. You're bothering me." (First Nations student)

Lack of accessibility is equated with lack of caring and lack of respect for the whole person. Kleinfeld (1975) describes the impersonal professionalism which is expected by universities to be antithetical to teacher effectiveness with First Nations students. These differences can lead to confusion by students who stated they often interpret a "formal" or "lecturing" attitude from a professor as disrespect:

'Cause a lot of times I feel like they're not going to care. They're going to yell at me which I know just sounds stupid, but you know you're just kind of "talked at" sometimes. (First Nations student)

These results are consistent with a body of literature that describes pedagogy in traditional aboriginal education as founded on a network of caring relationships (Hodgson-Smith, 2000). Kleinfeld (1975) states that this fundamental interpersonal orientation is culturally rooted in early family and peer-group experiences. While the quality of the professorstudent relationship has historically been undervalued in the academy, there is evidence that this dynamic is changing. Goldstein (1999) builds on previous theoretical work to suggest that when teacher and student enter the "relational zone" in a positive and caring way, intellectual transformation occurs. Thayer-Bacon and Bacon (1996) describe a model of good teaching that acknowledges the importance of caring and suggest that students learn more from caring professors. So, while this type of teaching relationship may be more culturally appropriate for First Nations students, it is likely that all students would benefit from more attention to the quality of the professor-student relationship.

\section{Theme Two: Including First Nations content in curriculum is a tool for facilitating student success. \\ Participants recommended that curriculum include specifically First Nations content. This theme emerged as more important for $U$ of $R$ faculty than for the SIFC group. This finding reinforces the importance of cultural relevance when participants are engaged in learning (Burhansstipanov,}


Table 2

\section{Theme Two: Including First Nations Content in Curriculum is a Tool for Facilitating Student Success}

Strategy

1. Use materials that include First Nations content

2. Include more positive and contemporary First Nations issues

3. Accept "first voice" stories as valid curriculum

4. Understand that curriculum is personal

\section{Example}

"The department, as a whole, has responded structurally and individually. We got the first wave of textbooks that began to incorporate some of that in the early $80 \mathrm{~s}$. And the response by the people who taught the introductory courses, which at that point is where we met Aboriginal people mostly, was to first of all incorporate that material." - $U$ of $R$ faculty

"They (U of R) never talk about First Nations' politics like fisheries and what's going on there. And I think if they involve more content relative to First Nations people that it would make the climate more warm." - First Nations student

"One very concrete thing I would recommend is to value oral history and to value stories that aren't written down. That's simple because in my experience going through university and also things that I hear from students, there are still a lot of professors who have no respect for oral history whatsoever. They won't accept it in paper - it's not true, it's rumor, it's hearsay, and so on."-SIFC faculty

"Often times, the students are directly related to people that we're talking about. And they may approach the material in a slightly different way because those stories are part of them."

- SIFC faculty 
1999). SIFC students stated that it is difficult to understand material that has no First Nations content:

What I noticed in (Faculty of Arts) classes... I find sometimes I just can't connect cause there's no cultural aspect to it. It's hard to approach I think in a way because it's not of our teachings. (First Nations student)

Regardless of the discipline, professors from the non-native institution sought out contemporary First Nations information to include in curriculum and lectures. For example, one Economics professor stated:

You can make little side efforts, you know. I make a point of talking about community property rights of the Plains Cree and the private property rights of the James Bay Cree and why they are different. This is of interest to the Aboriginal students, but it also turns out to be just a damn good example. ( $U$ of $R$ faculty)

McNinch (1992) states that curriculum must include distinctly First Nations' content rather than the broader multicultural content.

One strong recommendation for development of curriculum is for non-native faculty to recognize that oral tradition and storytelling are "legitimate" methods of transmitting knowledge in First Nations. Narratives written by $U$ of $R$ faculty described ways they were able to respect stories shared by First Nations students as told by their relatives:

An example is in an exercise I had my students do, I asked for an autobiographical memory exercise where they had to write about some particularly different experience in their life. And this one native student situated her story with respect to the story of her ancestors....and it's just a different way of telling a story. It's like there's no purely personal narrative in the native tradition. It's a continuation of the story of your ancestry. And those kinds of differences sometimes surface. And I think they're interesting. ( $U$ of $R$ faculty)

Valaskakis (2000) states that not only do traditional Native methods of information transmission and documentation differ from European methods, but the content is also very different; therefore, the use of oral history should be legitimized as a source of knowledge. Castellano 
(2000) also stresses that sources of traditional knowledge are transmitted in oral form through stories. However, participants cautioned that stories may mention relatives of students, so must be used respectfully.

\section{Theme Three: Teaching Methods; Learning is a Shared Endeavor and Cooperative Experience.}

A variety of teaching methods is recommended rather than the exclusive use of lectures. We found that cooperative learning models may be the most effective methods for facilitating success of First Nations students, which is consistent with previous studies that have identified cooperative strategies as most effective for Native students (Sawyer, 1991). One difference that emerged between the two faculty focus groups was that the SIFC faculty consciously create an atmosphere of equality and cooperation rather than competition in the beginning of each course by facilitating small group work. This result is similar to Kleinfeld's (1975) observation that effective teachers of Native students spent a substantial amount of time at the beginning of a course establishing positive interpersonal relationships, not only between teacher and student, but within student groups. Balancing lectures with class discussions throughout the semester is also helpful. However, faculty are cautioned to become familiar with appropriate verbal and non-verbal communication styles that may differ between cultures (Brant, 1993; Heit, 1987). For example, use of direct questions is often a disrespectful communication style for many First Nations students, so they may be at a disadvantage when they are expected to act contrary to cultural norms (Heit, 1987). Longer wait times between speakers allows students to "reflect" on what was previously said and build on, or add to, rather than critique or subtract from previous speakers' comments (Barnhardt, 1982; Bradley, 1980). This style of discourse is different from the competitive norm advocated in many academic environments.

Methods that are more holistic, experiential, and use the narrative mode are more consistent with traditional Aboriginal epistemology than are teaching methods that encourage a sequential, objective, and analytic orientation (Hampton, 1993; Hebert, 2000). The consensus among student participants was that "real life" assignments contribute to faster, long-term learning: "Real life assignments, projects and circles, they're pretty good, 
Table 3

\section{Theme Three: Teaching Methods; Learning is a Shared Endeavour and Cooperative Experience.}

Strategy

1. Attend to group process at the onset of the course

2. Balance lectures with opportunity for class discussion

3. Encourage group projects and "real life" assignments

4. Employ culture-fair evaluations methods

\section{Example}

"The idea of group work early... people feel a lack of confidence in their opinion, and whether they're going to make fools of themselves.

There's no such thing as a stupid question." - SIFC faculty

"I think with the native students, they like to have fairly clear free-flowing discussions of some of these things, rather than straight sort of lecture things. I think they like to sort of have an opportunity to toss some of these issues around and I guess hear what other people have to say about them" - SIFC faculty

"It taught me a lot about her development as an infant and as a child. I incorporated things and activities into the blanket because I knew it would encourage her development. I call that really, really good today."

- First Nations student

"In some ways it's not a lot different than teaching some of the (students) who are coming from other parts of the world. Incorporating things in examinations and what you're teaching to make sure they have an opportunity to tell you what they know from their own experience." $-U$ of $R$ faculty 
too, cause you get to learn more" (First Nations student). First Nations educators have described traditional and effective aboriginal teaching methods as "situated within the personal use and social domains" (Hebert, 2000, p. 69). This emphasis may explain why students say they learn more from "real life" assignments. For example, constructing a toy that illustrates developmental theory was cited as a useful learning activity (Neysmith-Roy, 1994).

Participants suggested that evaluation methods should be culturefair. Most evaluation methods used in university reflect cultural bias since they do not reflect First Nations cultural experience, and testing processes are often inappropriate (Chrisjohn \& Young, 1997; Duran \& Duran, 1995). For example, in writing essays, First Nations students may be more likely to use "iterative" or "spiral" than linear structure (Hampton, 1993). Similarly, some students are stronger in oral traditions rather than written English; as one student stated: "If I could say my term paper out loud I'd probably get better marks from the prof." In previous research, a professor of literature found that, by replacing written exams with oral exams in a course on American Indian literatures, the pedagogical match between course content, students' strengths, and evaluation criteria was more congruent (Sprayberry, 1996).

\section{Theme Four: Teaching Style; "You don't take a class, you take a person."}

A professor's teaching style reflects their cultural background; when there is a cultural match in the teacher-student interaction, research suggests there is less interference in the learning process (Hebert, 2000; Wilson, 1994). For non-native faculty this approach may begin with gaining cultural sensitivity. Faculty and student participants agree that professors who are open to learning about First Nations culture are more successful. Faculty report that the most beneficial cultural learning is experiential:

It is so important to actually have some knowledge of First Nations students. And I don't mean just kind of a glib knowledge. I feel terribly privileged. I grew up in this part of the country and my family has interacted with First Nations people, for example, for years and years and years. Every opportunity I get, Indian students are teaching me things. And this is just wonderful. I just feel richer and richer for it. And I think some 
Table 4

\section{Theme Four: Teaching style; "You Don't Take a Class, You Take a Person."}

Strategy

1. Seek opportunities to learn about First Nations culture

2. Show humility while teaching

3. Use humor

4. Create a relaxed classroom atmosphere

5. Show you are open to questions and differences

\section{Example}

"But that really challenges instructors that they have to learn, understand about the Aboriginal context. Getting to know some people. Getting that sort of feel to what's going on. A lot of people, when they come here, they don't think that it's important to get the context of the aboriginal community." - $U$ of $R$ faculty "I think in native communities, a sense of humility. Native people do not jump up and talk on a soapbox and say, "Look at me." So drawing attention to yourself by asking questions sometimes is a bit more difficult for native students than for non-native students. So you create the environment in which people feel comfortable doing that." - SIFC faculty "I like their sense of humor. It makes the class more at ease." - First Nations student

"A certain amount of informality is appreciated. I think it's very important so that people can open up." - SIFC faculty

"It's a feeling inside the class, too, that makes people want to come. Going back to it starts right at the prof. He's going to be open-minded. You look forward to coming to that class. Learning something plus having a good time there. Where everybody gets involved."

- First Nations student 
of us haven't had the opportunity. We really need to learn (about other cultures). ( $U$ of $R$ faculty)

An effective teaching style reflects First Nations cultural values which include humility, humor, and an open-minded attitude (Mitchell, 2000). One SIFC faculty member stated that her teaching style reflects humility in the following way: "You're not the authority here, you're just part of the big picture. It's just that you happen to know a little bit about the grammar or something." SIFC faculty also stated that sometimes First Nations students' reluctance to participate in class can be a reflection of humility: "So native students, they are not asking the questions in class doesn't mean they are disinterested. It's just that they don't like to draw attention to themselves." Humility and humor seem to support each other. SIFC faculty recommended that instructors be humorous, allowing oneself to be teased. One SIFC faculty member recommended: "Joke around. You know, probably the casual and informal atmosphere." Students appreciate professors who have a sense of humor because the learning is more enjoyable and the classroom climate is more harmonious.

When developing cultural sensitivity, non-Native professors who teach at both institutions described the importance of locating their own standpoint in respect to their cultural and racial origins:

I've learned a bit about my own historical/cultural/professional situation (as White, Anglo-Saxon, male, easterner, fulltime member of an academic community) relative to students - how their perception of me pre-conditions their relationship to knowledge. ( $U$ of $R$ faculty)

Caucasian instructors teaching at SIFC also described the importance of developing what researchers have described as White racial consciousness as well as acknowledging White privilege (Bennett, Atkinson, \& Rowe, 1993; Helms, 1990; Helms, 1992). One SIFC instructor wrote about how awareness of herself as a White teacher influenced her teaching style in a positive way:

A colleague who had taught on a reservation in the States took me out for coffee and gave me some solid advice. He told me that when I walked into the classroom (on a reserve), what my students would see was a middle class urban white 
woman, who looked and seemed pretty much like the women in TV ads or in glossy women's magazines. He said, "Your students will assume that your life is perfect and that you never screw up. Make sure you let them know that your life isn't perfect and that you do screw up. And be funny about it because these folks like to laugh. Twenty-five years later, I have shelves full of splendid books written by Canadian Aboriginal writers, and more shelves filled with theses and critical studies written about these books by our students. If I have a teaching problem, I just walk down the hall until I find a colleague and an answer. But at the beginning of every semester, I still return to the lessons I learned that summer at (the reserve): show that we're all fallible and we're all scared; keep the standards high, and laugh a lot.

University professors such as McIntosh (1988) have described the difficult personal journey demanded of White professors when they move beyond a colour-blind awareness to become more open-minded. Students confirmed that they can indeed tell whether a particular faculty member will receive them with openness or prejudice: "You can gauge whether they're going to be approachable or not I think by their attitude towards you when you approach them" (First Nations student).

Theme Five: Understand the life of a First Nations postsecondary student.

A collectivist rather than individualistic orientation to success tends to be more characteristic of First Nations motivation for learning, which may require professors to understand this cultural difference (Triandis, 1995). Our findings agree with previous research that suggests First Nations students define success in terms that include the relational dimensions of family and community as well as temporal dimensions such as contributing to multiple generations (Juntunen, Barraclough, Broneck, Seibel, Winrow, \& Morin, 2001). In addition, a more culturally appropriate description of the career path for First Nations students has been described as a "journey," with students sometimes relying on a traditional metaphor such as "hunting," or "visioning" as a guide in this journey (Cajete, 1994; Juntunen et al., 2001). SIFC faculty described 
Table 5

\section{Theme Five: Understand the Life of a First Nations Postsecondary Student}

Strategy

1. Motivate students through a positive sense of direction

2. Develop awareness of students' extended family obligations

3. Understand povertyrelated barriers to education

4. Recognize that racism is a reality for many First Nations students

\section{Example}

"First, for my self, I'm involved for the most part in culture, Native culture, sweat lodges, helping the youth understand their culture. So I see and $I$ hear the youth getting involved. That encourages me to be a good student and try to present them with a good role model.

- First Nations student

" 1 do notice the one thing, the extended family obligations. And the first time I was confronted with that, it didn't fit into my little perception of the family funeral. But you soon accommodate conceptions of the extended family, because a student feels just as strongly." $-U$ of $R$ faculty

"Simply that you take, let's say, a 22 year-old native student and a 22 year-old non-native. Like that 22 year-old native student likely has far more life experience." - SIFC faculty

"He got up in the middle of one of our classes after the midterm and said, 'This class is nothing but negative toward First Nations,' and a few other words that I won't repeat. But he never came back. And I understood up to that point that that's the way it's going to be. And it was too late for me to drop the class. I didn't want to get an NP. He got an NP. I went through because I can't fail the class. I cannot get an NP. Otherwise, I would have been out of there, too. I would have left because I didn't appreciate the instructor allowing racism, blatant racism, in the class. I couldn't stand it."-First Nations student 
the importance to students of a positive sense of direction as a motivator in their educational journey: "Understanding in the sense of direction. Positive sense of direction." This is a process-oriented concept rather than the individualized, short-term definition of success that is often used as a motivator in the non-Native world

For many students, involvement in traditional cultural activities reflects their positive sense of direction and gives meaning to their learning: "I think professors are really important when they understand a student and their cultural background" (First Nations student). For example, students may need to miss class to attend a Pow-Wow, or traditional ceremony, or to engage in subsistence activities. When students are supported in these activities, they will be more likely to succeed. Similarly, the more collectivist orientation to success reflects the way that participants in our study described their priority as family. For many students, the value of their education may be defined by the contributions they can make to the whole community; therefore family and community needs are sometimes of higher priority than academic assignments. As a result of poverty and other conditions of oppression, the mortality rate is much higher in First Nations, so students experience more funerals and family emergencies than non-First Nations students which may interfere with their academic studies (Belcourt-Dittloff \& Stewart, 2000; City of Regina, 1996). As one $U$ of $R$ faculty member reflects:

One of the things that I find is that there tend to be on average more emergencies for Aboriginal students. Well, deaths in the family. Not just in terms of older people, but also young people who die. One would [give that understanding] in terms of whether they're Aboriginal or White, but there tends to be a higher, I find on average, more emergencies for aboriginal students than there are for other students. ( $U$ of $R$ faculty)

To encourage success, one $U$ of $R$ faculty member stated that he works at understanding these issues and conveying his understanding:

There are many out-of-class issues, involving family, politics, lifestyle changes, personal backgrounds, that touch intimately on academic performance. These are not irrelevant to students' learning curves. 
Understanding the life of a First Nations student also means understanding the impact of racism as a historical as well as a daily experience that students endure on an individual and systemic basis (Clark, Anderson, Clark, \& Williams, 1999). Student participants in our research stated that they encounter it on an individual level from non-native students and instructors as well as from institutional policies. Becoming knowledgeable about the historical racism that has cumulatively affected First Nation peoples will help instructors minimize the effects (BelcourtDittloff \& Stewart, 2000).

\section{CONCLUSION}

We offer some action-oriented suggestions made by the participants in our study which have informed and enhanced our teaching practice. A significant finding in our research is that facilitating success of First Nations students begins with a positive professor-student relationship (Theme One). This result is similar to previous research investigating teacher effectiveness with Native students (Hampton, 1993; Kleinfeld, 1975; Wilson, 1994). It also validates traditional aboriginal pedagogy that describes teaching as an act of love which takes place within a trusting relationship (Castellano, 2000; Ermine, 1995; Hodgson-Smith, 2000). SIFC faculty consciously develop these relationships at the beginning of a course, whereas faculty in the non-native institution feel more pressure to deliver course content. The professional role expected of university teachers makes it difficult to be accessible and caring in the ways we recommend. Thayer-Bacon \& Bacon (1996) found that "caring" professors often leave the university setting because they are subjected to accusations of "unprofessional" behavior or devaluation of their teaching and research from colleagues. Our results allude to distinct cultural differences between the two institutions, wherein the First Nations-controlled institution supports the more culturally traditional teacher-student relationship.

The remaining three themes strive to achieve various levels of crosscultural competence (Burhansstipanov, 1999). Teaching that is truly competent would be culturally relevant, appropriate, and sensitive. Adapting curriculum to include First Nations content would make it relevant for 
these students. Delivering course content in verbal and non-verbal ways that respect First Nations' norms and values would help teaching style and methods become more culturally appropriate. Acknowledging cultural differences in beliefs and practices would contribute to enhanced sensitivity. Gaining experience in First Nations' culture was cited by participants as a helpful step toward more culturally competent teaching. Previous research has suggested that Native students in non-Native university settings are expected to be bicultural; and that those who are bicultural succeed (Lafromboise, Coleman \& Gerton, 1993). Our findings extend the responsibility for student success to instructors; those who strive for bicultural competence may be more effective at facilitating First Nations student success.

The strategies we describe are not merely techniques, but may require attitudinal and worldview changes. Many postsecondary faculty may already be teaching in these ways, so our results offer affirmations. But for most non-Native faculty, we're advocating personal development of such attitudes as racial consciousness and an open-minded attitude (Helms, 1992). Individual faculty need to be supported if they are to implement these strategies. In addition, recommendations in the literature suggest that change must be organizational in nature rather than in isolated subsystems of an educational institution (Sue et al., 1999). However, it would be a mistake to assume that as some individual faculty members change, the success rate of First Nations students will automatically increase. Changes need to be systematically and societally implemented to make big differences.

\section{References}

Barnhardt, C. (1982). Tuning in: Athabaskan teachers and Athabaskan students. In R. Barnhardt (Ed.), Cross-cultural issues in Alaskan education, Vol. II. Fairbanks, AK: University of Alaska, Center for Cross-Cultural Studies.

Battiste, M., \& Barman, J. (Eds.). (1995). First Nations education in Canada. Vancouver, BC: UBC Press.

Belcourt-Dittloff, A., \& Stewart, J. (2000). Historical racism: Implications for Native Americans. American Psychologist. 55(10), 1166-1167. 
Bennett, S.K., Atkinson, D.R., \& Rowe, W. (1993, August). White racial identity: An alternative perspective. Paper presented at the $101 \mathrm{st}$ Annual Convention of the American Psychological Association, Toronto, ON, Canada.

Bradley, C. (1980). A survey of Indian education in the northeast. Unpublished Manuscript. Cambridge, MA: Harvard Graduate School of Education.

Brant, C. (1993). Communication patterns in Indians: Verbal and nonverbal. Annals of Sex Research, 6, 259-269.

Brislin, R. W. \& Horvath, A.M. (1997). Cross-cultural training and multicultural education. In J.W. Berry, M.H., Segall, \& C. Kagitcibasi (Eds.), Handbook of crosscultural psychology (pp. 327-369). Toronto, ON: Allyn \& Bacon.

Burhansstipanov, L. (1999). Developing culturally competent communitybased intervention. In D. Weiner (Ed.), Preventing and controlling cancer in North America: A cross-cultural perspective (pp. 167-183). Westport, CT: Praeger.

Cajete, G. (1994). Look to the mountain. Colorado: Kivaki Press.

Castellano, M.B. (2000). Updating Aboriginal traditions of knowledge. In G.J.S. Dei, B.L. Hall, \& D.G. Rosenberg (Eds.), Indigenous knowledge in global context: Multiple readings of our world (pp.21-36). Toronto, ON: OISE.

Castellano, M.B., Davis, L., \& Lahache, L. (2000). Aboriginal education: Fulfilling the promise. Vancouver, $\mathrm{BC}$ : UBC Press.

Chrisjohn, R., \& Young, S. (1997). The circle game: Shadows and substance in the Indian residential school experience in Canada. Penticton, BC: Theytus.

City of Regina. (1996). Aboriginal Census. Regina, SK.

Clark, R., Anderson, N.B., Clark, V., \& Williams, D.R. (1999). Racism as a stressor for African Americans: A biopsychosocial model. American Psychologist. 54(10), 805-816.

Connelly, F.M., \& Clandinin, D.J. (1990). Stories of experience and narrative inquiry. Educational Researcher, June-July, 2-14.

Denzin, N.K. (1989). Interpretive Biography. Thousand Oaks, CA: Sage Publications.

Dei, G.J.S., Hall, B.L., \& Rosenberg, D.G. (Eds.). (2000). Indigenous knowledges in global contexts: Multiple readings of our world. Toronto, ON: University of Toronto Press.

Duran, E., \& Duran, B. (1995). Native American postcolonial psychology. New York, NY: SUNY Press.

Ermine, W. (1995). Aboriginal epistemology. In M. Battiste ,\& J. Barman (Eds.), First Nations education in Canada: The circle unfolds (pp. 101-112). Vancouver, BC: UBC Press. 
Fine, M., Weiss, L., Powell, L.C., \& Wong, L.M. (1997). Off white: Readings on race, power, and society. New York, NY: Routledge.

Frideres, J.S. (1998) Aboriginal peoples in Canada: Contemporary conflicts, 5thed. Scarborough, ON: Prentice Hall Allyn and Bacon Canada.

Goldstein, S. (1999). The relational zone: The role of caring relationships in the co-construction of mind. American Educational Research Journal, 36(3), 647-673.

Greenbaum, T.L. (1998). The handbook of focus group research, 2nd ed. Newbury Park, CA: Sage Publications.

Haig-Brown, C. (1988). Resistance and renewal: Surviving the Indian residential school. Vancouver, BC: Tillacum Library.

Hall, B.L., Kulig, J.C., Thorpe, K., \& Pfeuti, L. (1998). Understanding and application of culturally diverse issues within university settings. The Canadian Journal of Higher Education, 28(1), 105-128.

Hampton, E. (1993). Toward a redefinition of American Indian/Alaska Native education. Canadian Journal of Native Education, 20(2), 261-309.

Hampton, E., \& Wolfson, S. (1994). Education for self-determination. In J.H. Hylton (Ed.), Aboriginal self-government in Canada: Current trends and issues (pp. 91-107). Saskatoon, SK: Purich Publishers.

Hanson, I., \& Hampton, M.R. (2000). Being Indian: Strengths sustaining First Nations peoples in residential schools. Canadian Journal of Community Mental Health, 19(1), 127-142.

Hebert, Y. (2000). The state of aboriginal literacy and language education. In M.B. Castellano, L. Davis, \& L. Lahache, Aboriginal education: Fulfilling the promise (pp. 55-75). Vancouver, BC: UBC Press.

Heit, M. (1987). Communication styles of Indian peoples. Awasis - Indian and Native Education Council Journal, 5(1), March, 10-11.

Helms, J.E. (Eds.). (1990). Black and white racial identity: Theory, research and practice. Westport, CT: Greenwood Press.

Helms, J.E. (1992). A race is a nice thing to have: A guide to being a white person or understanding the white persons in your life. Topeka, KS: Content Communications.

Hodgson-Smith, K.L. (2000). Issues of pedagogy in Aboriginal education. In M.B. Castellano, L. Davis, \& L. Lahache. Aboriginal education: Fulfilling the promise (pp. 156-169). Vancouver, BC: UBC Press.

Huberman, A.M., \& Miles, M.B. (1998). Data management and analysis methods. In N.K. Denzin, \& Y.S. Lincoln (Eds.), Collecting and interpreting qualitative materials (pp. 179-210). Thousand Oaks, CA: Sage Publications. 
Indian and Northern Affairs Canada. (1989). Highlights of Aboriginal Conditions, 1981-1991, Part I, Demographic Trends, 4. Ottawa, ON: Department of Indian Affairs and Northern Development.

Indian and Northern Affairs Canada. (1990). Basic Departmental Data. Ottawa, ON: Minister of Supply and Services.

Jackson, S., \& Solis, S. (Eds.). (1995). Beyond comfort zones in multiculturalism: Confronting the politics of privilege. Westport, CT: Bergin and Garvey.

Janesick, F.J. (1998). The dance of qualitative research design: Metaphor, methodolatry, and meaning. In N.K. Denzin, \& Y.S. Lincoln (Eds.), Strategies of qualitative inquiry, (pp. 35-55). Thousand Oaks, CA: Sage Publications.

Juntunen, C.L., Barraclough, D.J., Broneck, C.L., Seibel, G.A., Winrow, S.A., \& Morin, P.M. (2001). American Indian perspectives on the career journey. Journal of Counseling Psychology. 48(3), 274-285.

Kleinfeld, J. (1975). Effective teachers of Eskimo and Indian students. School Review. 83, 301-345.

LaFromboise, T., Coleman, H.L.K., \& Gerton J. (1993). Psychological impact of biculturalism: Impact and theory. Psychological Bulletin. 114(3), 395-413.

Lieblich, A., Tuval-Mashiach, R., \& Zilber, T. (1998). Narrative research: Reading, analysis, and interpretation. Newbury Park, CA: Sage Publications.

Manning, P.K., \& Cullum-Swan, B. (1998). Narrative, content, and semiotic analysis. In N.K. Denzin, \& Y.S. Lincoln (Eds.), Strategies of qualitative inquiry (pp. 246-273). Thousand Oaks, CA: Sage Publications.

McIntosh, P. (1988). White privilege and male privilege: A personal account of coming to see a correspondence through work in women's studies. In P.S. Rothenberg (Ed.), Race, class, and gender in the United States: An integrated study, 4th ed. (pp. 291-299). New York, NY: St. Martin's Press.

McNinch, J. (1992). Multiculturalism and aboriginal teacher education. . Multicultural Education Newsletter, February, 3-6.

McNinch, J. (Ed.). (2001). First Nations and Metis students: A faculty guide. Regina, SK: University of Regina, Teaching Development Centre.

Miles, M.B., \& Huberman, A.M. (1994). Qualitative data analysis. Newbury Park, CA: Sage Publications.

Mitchell, H. (2000). Teaching from an Aboriginal perspective. Regina, SK: University of Regina, Teaching Development Centre.

Neysmith-Roy, J. (1994). Constructing toys to integrate knowledge about child development. Teaching of Psychology, 21(2), 101-103. 
Pederson, P. (Ed.). (1999). Multiculturalism as a fourth force. Philadelphia, PA: Brunner/Mazel.

Rhodes, R. (1994). Nurturing learning in Native American students. Hoteville: Sonwai Books.

Sawyer, D. (1991). Native learning styles: Shorthand for instructional adaptations? Canadian Journal of Native Education, 18(1), 99-105.

Simoni, J.M., Sexton-Radek, K., Yescavage, K., Richard, H., \& Lundquist, A. (1999). Teaching diversity: Experiences and recommendation of American Psychological Association Division 2 members. Teaching of Psychology, 26(2),89-95.

Smith, L.T. (1999). Decolonizing methodologies: Research and indigenous peoples. London and New York: Zed Books, Ltd.

Sprayberry, S.L. (1996). Corners, walls, and doors: The methodology of exams in a course on American Indian literatures. Studies in American Indian Literatures, 8, 21-27.

Statistics Canada. (1995). Profile of Canada's Aboriginal population. Ottawa, ON: Statistics Canada.

Strauss, A., \& Corbin, J. (1998). Basics of qualitative research: Grounded theory procedures and techniques. Newbury Park, CA: Sage Publications.

Sue, D.W., Bingham, R.P., Porche-Burke, L., \& Vasquez, M. (1999). The diversification of psychology: A multicultural revolution. American Psychologist, 54(12), 1061-1069.

Thayer-Bacon, B.J., \& Bacon, C.S. (1996). Caring professors: A model. The Journal of General Education, 45(4), 255-269.

Triandis, H.C. (1995). Individualism and collectivism. Boulder, CO: Westview.

Valaskakis, G.G. (2000). Telling our own stories: The role, development, and future of Aboriginal communications. In M.B. Castellano, L. Davis, \& L. Lahache. Aboriginal education: Fulfilling the promise (pp. 76-96). Vancouver, BC: UBC Press.

Wilson, P. (1994). The professor/student relationship: Key factors in minority student performance and achievement. The Canadian Journal of Native Studies, 14(2), 305-307. 